\title{
$\angle$ Research Square \\ Peacekeeping: The Role of Police in Peshawar Pakistan from 2013-2018
}

Shafi Ullah

University of Peshawar

Altaf Hussain ( $\nabla$ altafkfm74@gmail.com )

The University of Agriculture

\section{Case Report}

Keywords: Peacekeeping, Society Building, Good Work in Peshawar from 2019-2018, POLICE

Posted Date: August 17th, 2021

DOI: https://doi.org/10.21203/rs.3.rs-820248/v1

License: (9) This work is licensed under a Creative Commons Attribution 4.0 International License. Read Full License 


\section{Abstract}

Peacekeeping role is an important factor for the society and the people what lives under it accordingly. It has been there for centuries this think and phenomena to persuade people for their desire and their duty to be fully utilized. This is the active maintenance of a truce between nations or communities, especially by an international military force but in this perspective the military force are considered the POLICE. Peacekeeping comprises activities intended to create conditions that favour lasting peace. Research generally finds that peacekeeping reduces civilian and battlefield deaths and reduces the risk of renewed warfare. There are a range of various types of operations encompassed in peacekeeping such as Observation Missions, Interpositional Missions, Multidimensional missions and Peace enforcement Missions. Even though within the United Nations (UN) group of nation-state governments and organizations, there is a general understanding that at the international level, peacekeepers monitor and observe peace processes in post-conflict areas, and may assist ex-combatants in implementing peace agreement commitments that they have undertaken. In this research, the role of peacekeeping in Peshawar has been conducted as year wise from 2013-2018. This shows about five years gape and also reveals that how much changes have been done since then and now. Challenges and difficulties have been analyzed that Police have face in last 5 years. The role of peacekeeping has been examined in last 5 years and then these are evaluated with the contrast of the existing situations. From this study different types of results have been generated and portrayed in tables and graphs. For the purpose of investigating good work and the evaluation of peacekeeping perspectives and related methodologies have been conducted in which the important and key factors have shown that have a huge impact on peacekeeping role in society building.

\section{Introduction}

A state of peacefulness such as Freedom from civil disturbance and a state of security or order within a community or public provided for by law or custom. Different social scientist have different definitions but according to John Galtung a founder of peace and peace research has, among others proposed the important difference between "positive" and "negative" peace. "Positive peace means that concurrent presence of many disturbance and many required states of mind and society, such as harmony, justice, equity and so on. "Negative" peace has historically represented the "absence of war" and other forms of large scale violent human conflict (1).

Military operations undertaken with the approval of all major parties to a dispute designed to monitor and facilitate operation (cease fire, truce, or other such agreement between two parties and support diplomatic struggles to reach a political and social settlement and see also the peacebuilding, peacemaking, peace enforcement and peace operations (2).

Terrorism appears everywhere and is used by individuals, groups, and states. What is identified here is the use of violence by no state groups against non-combatants for symbolic determination, that is, to impact or somehow affect another audience for some political, social, or religious purpose. Such events seem to 
cluster, or to bunch, in world history, and it is suggested here that this clustering may hold a key to their understanding (3). Omar Lizardo \& Bergesen, Albert J. 2004

The events of September 11, 2001 were despite the shocking magnitude just a continuation in long term of bloody clash paid by groups see the targeting to the non-combats as a genuine tool for achieving their policy objectives (4). D.C Wills,2004

After the afghan war there is 5 million of refugees were shifted to Pakistan now these all refugees' effect on Pakistan. There are reports that Afghan refugees in Pakistan are being used by foreign agencies and are planning against the country, which has given them refuge for decades in their trying times. The economic cost of the continued stay of these refugees has been extremely high, particularly for KhyberPakhtunkhwa, where most of these refugees live. Even more than the economic effect, however, the bad security involvement of the presence of such a huge number of refugees in Pakistan is infinite (5). Dr. Raza Khan August 31', 2015

Pakistan's participation in the Afghan Jihad opened a violent period of terrorist consequences for the first time in the history of the country there were two concurrent waves of terrorist violence during this decade. Most of the attacks were arranged by Afghan and Soviet intelligence agencies, trying to make Pakistan to withhold its support for Afghan insurgents. Terrorist violence extreme's the Afghan Jihad entered the final phase. Peshawar, the platform for the Afghan rebellion, experienced most of these attacks. Wright discover that more Afghan commanders died in Peshawar than on the combat zone. Most of the terrorist activity at this time was focused in the Northwest Frontier Province (now Khyber Pakhtunkhwa), which is understandable given its geographical and cultural closeness to conflict-handle Afghanistan. The region was the base of conceptual and logistical support for the Afghan Mujahedeen. A total of $45 \%$ of terrorist incidences at this time happened in this province - and $30 \%$ of the incidences occurred in Peshawar alone (6). Roger P Merton, Habib Haider Sayed, Luqman Saeed,10 Jun 2014

The September 2008 Peshawar bombing was a bombing that occurred on 6 September 2008, in the boundary of Peshawar, KPK in earlier times known as North West Frontier Province (NWFP), Pakistan. A suicide bomber blew up at a police checkpoint, killing 35 and injuring 70. The December 2008 Peshawar bombing was a bombing that occurred on 5 December 2008 in Peshawar, killing 29 people and injuring over 100 others. Local police chief Naveed Khan suggested that chemicals intended to increase the spread of fire were control in the bomb. The 9 October 2009 Peshawar bombing was a coach bomb that was blow up at the crowded Khyber Bazaar in Peshawar on 9 October 2009 killing 41 and injuring at least 100.

On April 5, 2010, two bombings in Pakistan killed up to 50 people and injured 100 more. In the first attack the U.S. Consulate in Peshawar was attacked by militants. The 9 March 2011 Peshawar bombing occurred in the city of Peshawar, the capital of the Khyber Pakhtunkhwa province in north-west Pakistan. The attack took place in the Adezai locality of Peshawar; 37 people were killed and at least 45 were injured. The 2012 Pakistan airport attack was a correlate assault on 15 December 2012, by a team of 
terrorists who tried to enter Bacha Khan International Airport in Peshawar there is four citizens, and that more than 40 others had been injured. On 22 September 2013, a twin suicide bomb attack took place at All Saints Church in Peshawar in which 127 people were killed and over 250 injured. It was the destructive and more deadly attack on the Christian minority in the history of Pakistan (7).

In May 2013 general elections, Pakistan Tehreek-e-Insaf (PTI) came into power in KP. The PTI came out on the roads and blockade the NATO supply lines at Peshawar. Two months after this barrier, a terrorist attack on Dera Ismail Khan Jail in KP took place and it posed the first challenging incident for the PTI government to respond. On governmental side, the PTI regime made important reforms and new anti and counter terrorism laws were introduced, including the Explosive Substance Act, Control of Rented Buildings Act, Restriction of Hotel Businesses Act, Security of Sensitive, Poor Establishments Act and Police Act. The last quarter of 2014 witnessed the most shocking terrorist attack on the Army Public School (APS) Peshawar in which around 150 school children and adults were hard-hearted killed. In early 2015 , the next GATE stage was set for responding to the APS incident and its aftermath (8) Fakhr-ul-Islam \& Muhammad Quraish, 2018

By peacekeeping mean there is the use of military, police and civilian personal to take the base of sustainable peace. There is many types of peace keeping the traditional peacekeeping and broader peacekeeping. The traditional peacekeeping takes place the space between a ceasefire agreement and conclusion of a political settlement. Traditional peacekeeping do not force or propose the particular political solution but the want a belligerent and try to build the confidence between the political dialogues. And wider peacekeeping they develop the response to the breakdown of ceasefire or political agreement they enable the original deployment of traditional or assisting transition operation, combined with a belief on the part of peacekeepers that they should continue to have some sort of role in conflict area.(9) Alex J. Bellamy, Paul D. Williams, Stuart Griffin, 2010

\subsection{Structure of the study}

The structure of this study consist of five main chapters in which the entire study is completed. These five chapters present an introduction, a review of the literature, a research methodology, an analysis and a discussion, as well as conclusions and recommendation. By integrating the five chapters, a research maintained the correct flow of information throughout the study.

The second chapter of the study, the researcher incorporates the review of the literature, where all existing and current studies have been incorporated. In this chapter the researcher critically analysis the different procedure and techniques used to carry out the study in existing literature. In addition this chapter also describe the tools and approaches used for data collection and analysis.

The fourth chapter of analysis and discussion critically examined data collected to interpret the meaning and answer the main research question of this study. Finally in the last chapter, the researcher summarized all the discussions and results of the study and also provided the authorities with relevant recommendation regarding the effective study. 


\section{Literature Review}

This chapter explains the procedures of police against the society and for the refining of the society. In the current phenomenon it is being described that how for the society is protected by the police department in provincial and district levels. Also it deals with the rate of the crimes that police are investigating and solving in divide and conquer system. Police are the important face for the public living the existing society. They deals with all kind of activities that involve the help and law enforcement techniques. Police perform an efficient and best role in the society for the peace, livelihood and refine people in the existing society. The subsequent sections deals to give proper idea about police and their methods that for how long they keep the society at peace. Broadly speaking, that for how long do they achieve or perform in international or domestic level they have conducted for peace in prosperity to generate the desired activity of interest. In Pakistan the police departments of Khyber Pakhtunkhwa (KPK) was severely affected against terrorism operations many police were injured and martyred for the sake of country's peace. Since then this study examine and evaluate that for how long the activities of police department have been improved and how much achievements they have performed at annual and monthly level.

From their very beginning in the late nineteenth century, peace operations addressing internal or ethnic conflicts have included police modules. The U.N. created "civilian police," or CIVPOL for short, when they confirmed the Peacekeeping Force in Cyprus in 1964. Using the term "civilian" to differentiate it from military police (whose responsibilities are limited to the force itself), U.N. police monitors were to organize the Cypriot police. From 1989 on, most U.N. missions have included police modules. In peace operations, international police infrequently have the command to carry out law enforcement: usually weaponless, they are supposed to monitor and supervise the native law enforcement agencies. The "security gap" was highlighted in Herzegovina-Bosnia, because the military and the police components of the peace operation were handled by different agencies (NATO for the military, the U.N. for the police) Police alone are just one part of a fixed environment: together with a respected judiciary and a working prisons system they form part and package of the stable basis on which a democratic society can grow. Therefore, international police monitors often are mandated to supervise the judiciary and the prisons, too (1). Erwin A\& Schmidl, (1998)

Guaranteeing the safety of persons and property and restoring the public's trust in the maintenance of order and stability are the keys to any effort to reconstruct a working society after violent conflict. When the United States and its allies invest billions of dollars in a peace operation to mend a war-torn country which frequently is an important part of any conflict-settlement process the ultimate goal is to set the country on the path toward long-term stability. Physical security is a basic requirement for such stability, and security while initially enforced by an international presence ultimately must be maintained by the society's own police and legal system, not by outsiders. Thus, major tasks for the military disinterest conducting peace operations are to contribution in the betterment of indigenous mechanisms of law and order and to provide suitable means of support while the police forces and judicial structure of the 
operation's host country undergo the difficult process of reconstruction (2). Roxane D. V. \& Sismanidis(1997)

Civilian police have become such a sought-after service for use in peace support operations that the phrase 'international police peacekeeping' is now in common usage in the UN Department of Peacekeeping Operations. The terminology is, however, rather misleading, as police personnel may now be tasked with peace enforcement and peacebuilding tasks in addition to more traditional peacekeeping roles. Police personnel bring new capabilities and skill sets to sustain in peace operations, and operational difficulties regarding quantity, quality and standardization are beginning to be addressed. However, concerns over the connection of current policing models to post-conflict settings suggest that future international policing efforts would benefit from a closer attention of how to balance the demands of international and local policing norms (3). Bethan K\&Greener,11 March,2011

United Nations peacekeeping occupies a major place in Pakistan foreign policy agenda. In particular, the early 1990s were an active period for Pakistan, which served as a UN peacekeeper in various trouble spots throughout the world. There is two main points the first, although financial benefits may be a reason for participating in peacekeeping, it is argued that a combination of political interests has played a primary role in shaping Pakistan's positive attitude toward UN peacekeeping. Second is that Pakistan has also demonstrated a capacity to undertake peacekeeping in a way that meets some of the extraordinary needs emerging in the field today (4).K. krishnasamy,03 Feb 2011

In the country's struggle against violent extremism, Pakistani police officers have sacrificed their lives to save the lives of those around them. Heroic acts by the police have occurred in Peshawar, Quetta, and Karachi cities affected by the spread of terrorism from the tribal areas bordering Afghanistan. The acts of police heroism have done little to alter the fact that most Pakistanis fear the police and seek their assistance as a last option. Common corruption, high-handedness, and abusive behavior have soured police-community relations. Policemen routinely demand bribes, refuse to register cases, and, in the case of female crime victims, engage in harassment or worse. Forced confessions obtained by giving prisoners the third degree are common in a judicial system with little capacity for evidence-based prosecutions.

The origins of abusive police behavior are rooted in Pakistan's colonial past. Police in half the country's provinces still operate under an 1861 police law enacted following a major insurrection against British rule in 1857. The rank and file of Pakistan's 624,400-member police institutions are poorly educated, ill trained, badly equipped, underpaid, and working under inhumane conditions.

In Pakistan, the initial response to the growing threat from insurgency, terrorism, and violent crime was to create heavily armed antiterrorist units and distribute limited quantities of body armor, assault rifles, and armored vehicles to the regular police. The role of Pakistan's police in counterterrorism have focused on the need for new legal authorities, modern forensic and communication technology, armored vehicles, and heavy weaponry. Such improvements must be pursued, and current U.S. police assistance programs 
are providing valuable equipment, training, and infrastructure development (5). Tariq Parvez \& Robert M. Perito, 2013

Pakistan's law enforcement and police system is by no means too bad to fix. Moreover, at least within the police service, there is a discernible desire to improve performance. In comparative terms. A few effective counterterrorism operations in the late 1990s show that improvement and reform are indeed possible. The admirable performance of Pakistani police officers and junior officials while serving in various UN peacekeeping operations also show promise. Lately, many police officials across Pakistan have shown bravery in facing suicide bombing attacks. Brave police officers like Malik Saad and Safwat Ghayur who sacrificed their lives while leading from the front have inspired many young police officers in Pakistan.

For reform to take root along the lines suggested in the recommendations, however, Pakistan must first overcome internal spaces: political appointments must end; postings, recruitment, and promotions must be made on merit alone; and corrupt officers must be punished publicly. No financial resources are required to accomplish these goals. Second, Pakistan has to start investing its own funds in enhancing overall law enforcement capacity. International donors must understand that supporting the larger police and law enforcement reforms is the only effective way to enhance Pakistan's capacity to fight terrorism. Such support, besides strengthening the rule of law and democracy in the country, will improve interagency coordination for intelligence sharing and joint investigations with donor countries, which have acquired increased importance in recent times (6). Hassan Abbas, Feb 2011

Terrorism continues to challenge stability of many states across the world including Pakistan. In many modern and especially democratic states, police plays a critical role in fighting terrorism, but Pakistan's police has not been empowered and resourced to fight against terrorists. Capacity of police in this platform is a major issue. States affected by terrorism have constructed counter terrorism policies to eliminate terrorism but Pakistan took quite a while to formulate its first National Internal Security Policy (NISP). Now, as it has been formulated, it is a remarkable achievement for Pakistan in terms of a clear roadmap to counter terrorism. However, it has strangely ignored to define role of police in this range. The important point is that without an effective policing, countering terrorism may not be possible. Two variables which have been used is that are absence of political will for countering terrorism, and lack of capacity building of police. Absence of these two ideas has lengthy war against terrorism which has resulted in huge loss in terms of property and lives of people. Political will is to be achieved by generating consensus among national political leadership. For capacity building of police, huge amount of funds are also required and political elite will have to think beyond traditional use of police (7) Qamar Cheema \& Qurat-ul-Ain (2016)

Terrorism appears everywhere and is used by individuals, groups, and states. What is identified here is the use of violence by no state groups against non-combatants for symbolic purposes, that is, to influence or somehow affect another audience for some political, social, or religious purpose. Such events seem to cluster, or to bunch, in world history, and it is suggested here that this clustering may hold a key to their understanding (8). Lizardo, 0.\& Bergesen, A. J (2004). 
The events of September 11, 2001 were despite the horrific magnitude just a continuation in long term of bloody battle waged by groups see the targeting to the non-combats as a legitimate tool for fulfil their policy objectives. In the past such terrorist activities infrequently brought about any change in American policy, although in a few instance terrorist groups and sponsors met with spectacular success. In the case of September 11, Osama bin laden and his Al-Qaeda network demands that the United States end its support for Israel and the Saudi regime, and remove its forces from the Persian Gulf especially from Saudi Arabia (9). Wills, D. C. (2004)

After the afghan war there is 5 million of refugees were shifted to Pakistan now these all refugees' effect on Pakistan. There are reports that Afghan refugees in Pakistan are being used by foreign agencies and are collaborate against the country, which has given them refuge for decades in their trying times. The economic cost of the continued stay of these refugees has been extremely high, particularly for KhyberPakhtunkhwa, where most of these refugees live. Even more than the economic fallout, however, the adverse security implications of the presence of such a huge number of refugees in Pakistan is incalculable (10). Dr. Raza Khan August 315t, 2015

Police plays a vital role in the law enforcement in any country of the world. Historic Police Reforms introduced in the Khyber Pakhtunkhwa Police as a vision of Pakistan Tehreek-e-Insaf has made it the best Police force in the country. Before the Election, Imran Khan was promised with the nation to bring police reform to make it corruption FREE and non-political. Undoubtedly the present KP government in the province has fully authorized the police department with the introduction and implementation of Police Ordinance 2016. This Ordinance has made the Police department an autonomous body fully independent of political interference and completely authorized to freely work for the public safety and well-being. Journalists and analyst agreed that there is no comparison of KPK Police in Pakistan as it got developed so fast in last three years.

The police in KP today are ever more accountable where postings, transfers and promotions have been linked with performance. Hundreds of police officials punished on corruption charges exemplify the accountability mechanisms in place within the KP police.

These are some of the Top Tech reforms which made it the most advanced police in Pakistan.

- Digitization of FIRs

- Tenant Information System

- Identity Verification System

- Vehicle Verification System

- Criminal Record Verification

- Geo-Tagging

- SOS Alert Service

- Police Access Service (PAS) 
- Dispute Resolution Council (DRC)

These reforms enable the public to develop their trust on the police for the creation of a harmonious and peaceful atmosphere (11).

\section{Theoretical framework:}

According to Robert $\mathrm{K}$ Merton argued that functionalism is about the more static or concrete aspects of society. This theory explains that why society functions the way it does by emphasizing on the relationships between the various social institutions that make up society (e.g. government, law, education, religion, etc.).

The structural-functional approach is a perspective in sociology that sees society as a complex system whose parts work together to promote solidarity and stability. It asserts that our lives are guided by social structures, which are relatively stable patterns of social behavior. Social structures give shape to our lives - for example, in families, the community, and through religious organizations.

\section{Structural Functionalism}

"Structural functionalism concentrates on the positive and negative functions of social structures. Societal functionalism is a particular type of structural functionalism that aims to explain the role of social structures and institutions in society, the relationship between these structures, and the manner in which these structures constrain the actions of individuals. According to structural functionalists, individuals have little to no control over the ways in which particular structures operate. Indeed, structural functionalists understand individuals in terms of social positions. For example, when the structural functionalists Kingsley Davis and Wilbur Moore discuss social stratification, they do not refer to individuals, but to the positions these individuals occupy. It is not individuals who are ranked, but positions that are ranked according to the degree to which they contribute to the survival of society. Highranking positions offer high rewards that make them worth an individual's time and effort to occupy. The structural functionalist account of stratification has been criticized on the grounds that there must be other ways to motivate individuals to occupy particular positions and perform certain tasks without such a disparate system of rewards.

\section{Talcott Parsons's Structural Functionalism}

2nd ) Structural functionalism, or in many contexts simply functionalism, is a broad perspective in sociology and anthropology which sets out to interpret society as a structure with interrelated parts. Functionalism addresses society as a whole in terms of the function of its constituent elements; namely norms, customs, traditions and institutions.

\section{Research Design}

\subsection{QUESTION OF THE STUDY}


How effective the police have been in countering crime in Peshawar in the last five years?

Why people satisfy from police department?

By satisfy mean are the people in Peshawar they are happy with the police and they feel safe.

\subsection{UNIVERSE OF THE STUDY}

The study was conducted in Peshawar for data collection, for this purpose Capital City Police Office and police line were selected and data only collected from male officers.

\subsection{SCOPE OF THE STUDY}

This study was confined to know about the counter terrorism in Peshawar and the role of police and his sacrifice for peace. The data collection from police line for researchers is accessible. All type of respondent is also comfortable available in the particular universe.

\subsection{Objectives of the study}

i. To analyses the challenges that police faced in peace keeping in the last 5 years.

ii. To examine the role of police in peacekeeping in the last 5 years.

iii. To assess the government in enhancing police capabilities to cope peace keeping.

\subsection{DEPENDENT VARIABLE}

a. Structural functionalism Theory by Herbert Spencer and Robert K Marten

\subsection{METHODOLOGY}

Every research in social science depend upon certain method and tools for data collection, which a social researcher obtain a data of reliable facts for analyses. Different steps taken for the data collection are given below under different subtitles:

\subsubsection{Nature of the study}

Qualitative \& Quantitative

A schedule interview is taken from each individual separately, and the respondents will be the police officers who have been the part of peacekeeping operations. And then it will analyzed and compare with the topics under study for required data collection. Interview is selected for the reason that the public and police constables are not aware of the process of peace operations. And many of these are uneducated and not fill the questionnaire. And the data will also be taken in quantitative in nature. The data of crime reports and achievements of Peshawar police since 2013 to 2018

\subsubsection{Method of the study}


The method used during this study was the data collection and then scheduled interview from some respondents.

\subsection{TOOLS OF DATA COLLECTION}

Both the primary and secondary data will be used in this research. In secondary data we will take data from the capital police the data will be the total crimes, attempt crime, robbery, arms etc in District Peshawar from 2013 to 2018. In primary data there will be structural interview schedule has used as tool for data collection. The interviews have executed from only police officers in Peshawar police line. Also library approach, government reports, news articles and social media. In addition of informal interviews were taken from SSPs.

\subsection{SAMPLE OF THE STUDY}

Purposive sampling made during the study. Respondent have been selected from universe according to need the study. The study is conducted in police line Peshawar. Three respondent were selected in this research.

\subsection{THE CONDUCT OF THE INTERVIEW}

The researcher has implemented the interview for data collection. The researcher in person executed interview schedule. The interview were conducted in their native language at police line Peshawar. All the interviewers cooperated in conducting the interview.

\subsection{SIGNIFICANCE OF THE STUDY}

i. In addition the study will help us to check upon the rise and fall in the crime rate of Peshawar.

ii. Exploration and efforts of police for peace keeping.

iii. To know about the reforms in police.

\subsection{PRE TESTING}

\subsection{DATA ANALYSIS}

After the completion of data collection process, all the data collected from various sources was tabulated under different and appropriate captions. The data was statistically analyzed.

\subsection{LITERATURE REVIEW}

The researcher collected all the available literature related to the study, studied them thoroughly and extracted pertinent portions as base for and endorsement of the study. All the material taken from different sources were properly arranged in the chapter two of this report.

\subsection{DELIMITATION}


The study has conducted only in district Peshawar, reason are:

i. Easy to communicate and understand the point of view of police officers.

ii. As for the study area is concerned, only police will be respondent for data collection.

\subsection{STATEMENT OF THE PROBLEM}

The Police of Pakistan during the phase of war and terror after 9/11 faces many problems. The structure of Police is very bad, especially in Peshawar. When the Afghan refugees shifted to Pakistan due to this the population of Peshawar increases and this create many issues for police. The crimes rate increases and the peace of Peshawar is disturbed due to over increasing population. The circumstances of the city from 2008 to 2013 is very worst. Terrorism in high peak and bomb blasts and others terrorist activities, crimes, murders is in high level. After 2013 the police structure is changed and many reforms occur like online FIR system, CTD department is separate from police department then the burden his been distributed on different institutions. Elite force is made and others police training schools. Police have lots of sacrifices for the sustainable peace in Peshawar.

\subsection{FIELD VISIT TO CITY POLICE OFFICE / POLICE LIN}

The Peshawar police line is located in the capital of Khyber Pakhtunkhwa. This building is near to two important building the one is Peshawar high court and another one is provincial assembly of Khyber Pakhtunkhwa.

By the time of data collection on date 15/7/2019 I and my friend Sajjad Khan visit to police line everything is completed which above mention. Before the visiting to police line the researcher write a permission latter to capital city police. On the first day of visit to police line there is many check posts to check the bags and documents to allow the researcher for collect data. There is three different type of check points through which have verify your identity and the reason of visit and then call to concerned person which you want to meet then they reply to check point that to allow the researcher to inside police line.

After passing these all checkpoints there is the main office of SSP Operation Mr, Zahoor Babar Afridi where is guard took authority latter and forward to SSP and want to researcher to wait until his any clearance has issued. After half an hour the PA to SSP call the researcher to inside his office to ask some questions about the research and data collection and purpose of the study and also some personal question from research to verification of the identity of the researcher. And then he transfer to SP then we met with SSP Coordinator Mr. Waseem Riaz. We give all information about the research then he says that we will contact you when your data is ready SP call to office and says that collect the crime data from 2013-2018 in Peshawar. After one week the SP of Peshawar call me to come to police line and receive your crime data. Then 29 August we again visit to Police line for structure interview then we direct met with SSP Operation and then he calls to SSP coordinator Mr Sarfaraz Ali Shah and SP Head Quarter Abdu's Salam Khalid and then we ask some questions and both SSP and SP give very brief answer and 
these interviews is very friendly mood.we learn more things about the Peshawar police and his efforts for peace in Peshawar.

\section{Data Analysis}

\section{Table 4.1 Murder Cases per year in Peshawar}

\begin{tabular}{|ll|}
\hline Year & Murder \\
\hline 2013 & 623 \\
\hline 2014 & 695 \\
\hline 20015 & 456 \\
\hline 2016 & 493 \\
\hline 2017 & 417 \\
\hline 2018 & 295 \\
\hline
\end{tabular}

\section{Explanation:}

The given graph is about the murder cases per year. The graph shows us two values which are Years and murder cases. There are shown five years which are 2013,2015,2016,2017 and 2018. Against every year there are values of murder cases which handle in the given year. According to graph in 2013 the murder cases are 623, in 2014 the cases are 695, in 2015 the cases are 456, same here 2016 the cases are 493, in 2017 the cases are 417 and at last 2018 the murder cases are 395.so the graph shows us the lowest number of cases occur in 2018 which are 395 and the highest cases are 695 in 2014.

\section{Table 4.2 Attempted Murder Cases per year in Peshawar}

\begin{tabular}{|ll|}
\hline year & Attempted Murder \\
\hline 2013 & 641 \\
\hline 2014 & 701 \\
\hline 2015 & 620 \\
\hline 2016 & 597 \\
\hline 2017 & 539 \\
\hline 2018 & 520 \\
\hline
\end{tabular}

\section{Explanation:}


The given graph is about the murder cases per year. The graph shows us two values which are Years and murder cases. There are shown five years which are 2013, 2014, 2015, 2016, 2017 and 2018. Against every year there are values of murder cases which handle in the given year. According to the graph in 2013 the murder cases are 623, in 2014 the cases were 695, in 2015 the cases were 456, same here in 2016 the cases were 493, in 2017 the cases were 417 and at last in 2018 the murder cases were 395.so the graph shows us the lowest number of cases occur in 2018 which are 395 and the highest cases are 695 in 2014.

\section{Table 4.3 Kid Ransom cases per year in Peshawar}

\begin{tabular}{|ll|}
\hline Year & Kid ransom \\
\hline 2013 & 56 \\
\hline 2014 & 69 \\
& \\
\hline 2015 & 28 \\
\hline 2016 & 8 \\
\hline 2017 & 12 \\
\hline 2018 & 4 \\
\hline
\end{tabular}

\section{Explanation}

The given graph is about the Kid ransom cases per year. The graph shows us two values which are Years and Kid ransom. There are shown five years which are 2013, 2014, 2015, 2016, 2017 and 2018. Against every year there are values of Kid ransom cases which handle in the given year. According to the graph in 2013 the Kid ransom cases are 56, in 2014 the cases were 69, in 2015 the cases were 28, same here in 2016 the cases were 08, in 2017 the cases were 12 and at last in 2018 the Kid ransom cases were 04.so the graph shows us the lowest number of cases occur in 2018 which are 04 and the highest cases are 69 in 2014.

\section{Table 4.4 Ord:Dacoity Cases per year in Peshawar}




\begin{tabular}{|ll|}
\hline Year & Ord:Dacoity \\
\hline 2013 & 16 \\
\hline 2014 & 27 \\
\hline 2015 & 22 \\
\hline 2016 & 22 \\
\hline 2017 & 20 \\
\hline 2018 & 14 \\
\hline
\end{tabular}

\section{Explanation}

The given graph is about the Ordinarys Dacoity cases per year. The graph shows us two values which are Years and Ord: Dacoity cases. There are shown five years which are 2013, 2014, 2015, 2016, 2017 and 2018. Against every year there are values of Ord: Dacoity cases which handle in the given year. According to the graph in 2013 the Dacoity cases are 16, in 2014 the cases were 27, in 2015 the cases were 22, same here in 2016 the cases were 22, in 2017 the cases were 20 and at last in 2018 the Ord: Dacoity cases were 14.so the graph shows us the lowest number of cases occur in 2018 which are 14 and the highest cases are 27 in 2014.

Table 4.5 Burglary Cases per year in Peshawar

\begin{tabular}{|ll|}
\hline Year & Burglary \\
\hline 2013 & 154 \\
\hline 2014 & 192 \\
\hline 2015 & 175 \\
\hline 2016 & 162 \\
\hline 2017 & 140 \\
\hline 2018 & 142 \\
\hline
\end{tabular}

\section{Explanation}

The given graph is about the murder cases per year. The graph shows us two values which are Years and Burglary cases. There are shown five years which are 2013, 2014, 2015, 2016, 2017 and 2018. Against every year there are values of Burglary cases which handle in the given year. According to the graph in 2013 the Burglary cases are 154, in 2014 the cases were 192, in 2015 the cases were 175 same here in 2016 the cases were 162, in 2017 the cases were 140 and at last in 2018 the murder cases were 142.so the graph shows us the lowest number of cases occur in 2017 which are 140 and the highest cases are 192 in 2014 


\begin{tabular}{|cc|}
\hline Year & Arms \\
\hline 2013 & 5496 \\
\hline 2014 & 5740 \\
\hline 2015 & 4501 \\
\hline 2016 & 4899 \\
\hline 2017 & 5009 \\
\hline 2018 & 5452 \\
\hline
\end{tabular}

\section{Explanation:}

The given graph is about the Arms cases per year. The graph shows us two values which are Years and Arms cases. There are shown five years which are 2013, 2014, 2015, 2016, 2017 and 2018. Against every year there are values of Arms cases which handle in the given year. According to the graph in 2013 the Arms cases are 5496, in 2014 the cases were 5740, in 2015 the cases were 4501, same here in 2016 the cases were 4899, in 2017 the cases were 5009 and at last in 2018 the Arms cases were 5452.so the graph shows us the lowest number of cases occur in 2015 which are 4501 and the highest cases are 5740 in 2014.

\section{Table 4.7 Potentially Hazardous Object Cases in Peshawar}

\begin{tabular}{|ll|}
\hline Year & PHO \\
\hline 2013 & 7392 \\
\hline 2014 & 5557 \\
\hline 2015 & 7017 \\
\hline 2016 & 9248 \\
\hline 2017 & 9109 \\
\hline 2018 & 11767 \\
\hline
\end{tabular}

\section{Explanation:}

The given graph is about the Potentially Hazardous object cases per year. The graph shows us two values which are Years and PHO cases. There are shown five years which are 2013, 2014, 2015, 2016, 2017 and 2018. Against every year there are values of PHO cases which handle in the given year. According to the graph in 2013 the PHO cases are 7392, in 2014 the cases were 5557, in 2015 the cases were 7017, same here in 2016 the cases were 9248, in 2017 the cases were 9109 and at last in 2018 the 
PHO cases were 11767.so the graph shows us the lowest number of cases occur in 2014 which are 5557 and the highest cases are 11767 in 2018.

Table 4.8 Ord: Robbery Cases per year in Peshawa

\begin{tabular}{|ll|}
\hline Year & Ord: Robbery \\
\hline v 2013 & 23 \\
\hline 2014 & 49 \\
\hline 2015 & 54 \\
\hline 2016 & 52 \\
\hline 2017 & 108 \\
\hline 2018 & 116 \\
\hline
\end{tabular}

\section{Explanation}

The given graph is about the Ordinary Robbery cases per year. The graph shows us two values which are Years and Ord: Robbery cases. There are shown five years which are 2013, 2014, 2015, 2016, 2017 and 2018. Against every year there are values of Ord: Robbery cases which handle in the given year. According to the graph in 2013 the Robbery cases are 23, in 2014 the cases were 49, in 2015 the cases were 54, same here in 2016 the cases were 52, in 2017 the cases were 108 and at last in 2018 the Ord: Robbery cases were 116. So the graph shows us the lowest number of cases occur in 2013 which are 23 and the highest cases are 116 in 2018.

\section{GOOD WORK FROM 2013-2018 Arms and Ammunitions}

\section{Recovery}

Table 4.9: Recovery of Arms and Ammunitions from 2013-2018. 


\begin{tabular}{|lllllll|}
\hline Weapons & $\mathbf{2 0 1 3}$ & $\mathbf{2 0 1 4}$ & $\mathbf{2 0 1 5}$ & $\mathbf{2 0 1 6}$ & $\mathbf{2 0 1 7}$ & $\mathbf{2 0 1 8}$ \\
\hline Rounds & 658123 & 558996 & 307332 & 422463 & 313194 & 639273 \\
\hline Kala Kov & 78 & 107 & 82 & 72 & 77 & 60 \\
\hline Rifle & 270 & 296 & 259 & 324 & 425 & 446 \\
\hline Shot Gun & 574 & 726 & 1103 & 933 & 926 & 826 \\
\hline Hand Grenade & 166 & 86 & 143 & 114 & 115 & 34 \\
\hline Prime Cords & 8192 & 9169 & 6612 & 247 & 199 & 34 \\
\hline Launcher & 1 & & 1 & 2 & 5 & 4 \\
\hline Bomb & 4 & 5 & 4 & 7 & 8 & 1 \\
\hline Detonator & 1890 & & 4033 & 54 & 620 & 309 \\
\hline Mines & & 12 & & & & 3 \\
\hline LMG & 1 & & 4 & 1 & 2 & 2 \\
\hline Pistol & 5978 & 5872 & 5638 & 6378 & 5954 & 5498 \\
\hline Shells & 16 & 148 & 45 & 16 & 61 & 18 \\
\hline Fuse/Booster & 1810 & 18 & 27 & 115 & 60 & 14 \\
\hline Suicide Jacket & 5 & 1 & 7 & & 4 & 1 \\
\hline Missiles & & & & 3 & & 678 \\
\hline Kalashnikov & 603 & 652 & 631 & 602 & 651 & 69.12 \\
\hline Explosive Material & 26990.55 & 239.678 & 901.348 & 194.95 & 349.000 & \\
\hline
\end{tabular}

The term weapon is any instrument or instrumentality used in fighting or hunting while ammunition is any nuclear or chemical or biological material that can be used as a weapon of mass destruction. As depicted in Table 4.9, the ratios of arms and ammunitions have shown some alternative results from the recovery. It has been portrayed in the given Table which has shown some drastically changes by the kind of weapon. And some has shown the level of weapons decreased in many years as shown in the Table. The values of these have different altitudes from the perspectives of the recovery specialists that some of them have increasing day by day and some has shown potential decreasing. As it can be seen from the Table that the ratios are not the same i.e. some have increased in some years and decreased in different weapons from year 2013 to 2018 . Different kinds of weapons are recovered if taking into considerations the first row of the table represents the rounds along with separate values from year 2013 to 2018 . In synopsis, it is the good work that have been portrayed in the table and also shown in the Figure 4.9(a) and (b). By the use of tactical forces and strict search operations these weapons and ammunitions may also come to the lowest point in recovery as there will be no more people to toying with these weapons and spreading terrorism. 
The values of these two Figures i.e. 4.9(a) and (b) are the graphical illustration of the table 4.9. These values have shown a tremendous change from year 2013 up to 2018. Rounds, bombs, hand grenade, pistols, guns etc. kind of weapons have been recovered in six years gape. The summary and average of these recovery shows that the level of weapons have decreased on some kinds and also some have shown that the level is tending towards the excessive range. The values of rounds were too high in contrast to others that why it was portrayed in separate graph for understanding and comparison-based perspective.

\section{Recovery of Narcotics}

Table 5.1: Good-Work from 2013-2018 shows Recovery of Narcotics.

\begin{tabular}{|lllllll|}
\hline NARCOTICS & $\mathbf{2 0 1 3}$ & $\mathbf{2 0 1 4}$ & $\mathbf{2 0 1 5}$ & $\mathbf{2 0 1 6}$ & $\mathbf{2 0 1 7}$ & $\mathbf{2 0 1 8}$ \\
\hline Charas & 13831.438 & 4531.013 & 4449.045 & 4592.101 & 5458.169 & 6026.022 \\
\hline Heroin & 153.682 & 541.304 & 258.212 & 195.601 & 221.269 & 243.422 \\
\hline Opium & 76.865 & 211.802 & 224.355 & 157.265 & 83.185 & 268.879 \\
\hline Alcohol (BTL) & 9560 & 7939 & 6144 & 3796 & 3616 & 6547 \\
\hline Liquor & 1996.000 & 3277.000 & & 7995.000 & 4800.000 & 8212.000 \\
\hline ICE & & & & & 6.112 & 20.224 \\
\hline
\end{tabular}

As depicted in Table 5.1, the term narcotics used for sedation and addicted kind of people that are addicted to it for getting high. It can be also expressed that a drug that produces numbness or stupor; often taken for pleasure or to reduce pain; extensive use can lead to addiction. It can also be used for medical terms like sedation, local anesthetic during the time of surgery and for psychiatric patients. Taking into considerations, the youth of recent are using it for exclusive bad habit. That shows some negative perspectives in the society as well as the youngsters are sabotaging their lives by taking these kinds of narcotics. The Table 5.1 shows the recovery of narcotics per year along with different perspectives from year 2013 up to 2018. It illustrates that some changes have been done in some kinds of narcotics but some have shown exceeding range from year 2013 up to 2018. For e.g. to take into account the measurement of Marijuana (charas) has shown the decreasing range from 2013 to 2018. In 2013 the level of charas shows 13831.438, in 2014 it shows 4531.013 and so on. But in 2018 the level of marijuana shows 6026.022 which is the half of the level of 2013. From this perspective every row in the given table shows that the values have dropped from excessive level to the decrement level. That explains the good work of the anti-narcotics specialists during recovery. The overall average of the given table has shown dramatic change from first row to last. Charas has shown 6481.298 averages, similarly Heroin has shown 268.915, Opium has shown 170.3918, Alcohol (BTL) has shown 6267, Liquor has shown 5256 and finally ICE has shown 13.168 Average. The values of the above table has portrayed in the given graph for graphical illustration and to show statistical representation efficiently in the form of increasing and decreasing level. 
As illustrated in Figure 5.2, the values of different classes of narcotics have shown different changes from year 2013-2018. As these have been portrayed and discussed with divergent perspectives but it should also be mandatory to define each class of narcotics. The first one is Marijuana (charas) is a strong-smelling plant from whose dried leaves a number of euphoriant and hallucinogenic drugs are prepared. Also it is the most commonly used illicit drug; considered a soft drug, it consists of the dried leaves of the hemp plant; smoked or chewed for euphoric effect. The second one is Heroin that can be defined, as a narcotic that is considered a hard drug; a highly addictive morphine derivative; intravenous injection provides the fastest and most intense rush. The third one is Opium can be defined as, an addictive narcotic extracted from seed capsules of the opium poppy. The fourth one is alcohol (BTL) is a liquor or brew containing alcohol as the active agent. The fifth one is Liquor, an alcoholic beverage that is distilled rather than fermented, also called it booze and spirits. The last one is ICE, an amphetamine derivative (trade name Methedrine) used in the form of a crystalline hydrochloride; used as a stimulant to the nervous system and as an appetite suppressant.

In summary, by reviewing these narcotics it has been witnessed that it is the good work of recovery and it also shows that the range of these narcotics are decreasing day by day by recovery and strict law that these are prohibited and forbidden for pleasure or personal use to gain the pleasure of mind and mood. There is still hope that in future by the good work of anti-narcotics; these cases may be altered into the decreasing amount.

\section{Analysis:}

The given data which is collected from capital police is given above and after the analysis is has been observe that the crime has been fall down with the passage of time by the effort of police and security agencies. If we take the example of murders which were 623 in the year of 2013 and 695 in 2014 and 456 in 2015 and 493 in 2016 and 417 in 2017 along with the data of 2018 is 395 in numbers so hence it is proved the murders falls down from 623 to 395.

We will take it on a large scale that the population of 2013 to 2015 was recorded by election commission of Pakistan the population censes and the population was recorded 1,970,042 In which the crime of those three years was 40,304 given by capital city police and the data of population recorded in 2018 by population censes the population of Peshawar district 4,269,079 and the crime of these three years were recorded by capital police is 49,209 so the crime is increases by the time but if we calculate the data of using the crime rate formula like $A$ crime rate is calculated by dividing the number of reported crimes by the total population; the result is multiplied by 100,000 . For example, in 2010 there were 58,100 robberies in California and the population was $38,826,898$. This equals a robbery crime rate of 149.6 per 100,000 general population. we will found the that the crime rate of 2013 to 2015 is 2045.89 while in the years of 2016 to 2018 the crime rate is 1152.68 so hence it is proved that the crime rate falls down by the reforms in security agencies specifically police of Peshawar Pakistan.

\section{Anexure}




\section{$1^{\text {ST }}$ RESPONDENT}

Q1: the basic thing is in this when you see someone's society you see the reflection of police whatever the society is society gets a police system which it deserve. Because police is come from this society. The mentality which the society have same mentality come in the police. in these things are reflected and effected in the police department if your police seems positive, polite, obedient, loyal and intelligent it mean the society is like that police is represent your society . the basic characteristic in the police you see that shows the face of the society lets suppose the police obey the law just like the issue when someone don't wear helmet on motorcycle how the other people learn a lesson from them.

Q2: when you see before the militancy and when the militancy comes you see the different police. The militancy comes onward from 2007-2008 the police face difficulties and sacrifices after that lots of things have been improved in the department . a big war against the terrorism the police is on frontline like badhaber and matani which is called no go area they are fight on frontline with the warriors in a limited resources they never back. The passage of time increasing the headcount and advance technology new gadgets brings the control on militancy.

Q3: there is two parts of it the one is operational part and the other is investigation.our basic duty is to protect life and property. you can see area by area blockade and rider squads and mobiles. You can see always the safe city mobiles and you can see educational institutions rapid response force and quick response force RRF and URF they are all insuring .like agriculture attack ,we lost 9 or 10 caulaties it might be 90 or hundred just like APS.but there was mobile response when they inter they limit the terrorist tp the one building if they allow to police the other building or hostel there might be lots of destruction. The life and property is insure over there police have face lots of losts recently our riders his been martyred in paharipura. he was fighting with street criminals. You can see the crimes is going down. The same way we are tired of funerals. These all are for the sake of insure the safety of the public property and life.

Q4:look partially we can say it may be in the right of one or two persons but you cant measure in a larger circle you can't agree with this statement .police his to deal with two parties the one is true and the other is lie if I go with the truth the liar will say I am with the other and I have to decide one its upon me if someone is wrong its very easy to blame the police and simply he can say the police take money. The confusion and register cases the people are not aware of cognizable and non cognisable offence. There are offences, murders, robbery under the view of low are cognizable. Police is direct write FIR and arrest. We have about seventy or eighty percent wife and husband issues which cant be resolved by simple methods or simple inquiry . there is department they have a family courts this is civil nature case. Some relatives have a property issue police cant resolve it . the court will take decision finally like banking issues etc these are all not cognizable police cant resolve. The courts allow was some sort of stages like someone comes and we know that he is speaking lei then initially we do inquiry the law give us this remedy, responsibility and after the inquiry I will decide whether I go for FIR or not that all the part of investigation. 
Q5:before 2013 and 2014 the police joins the department they will decide by us directly. Now the police comes with merit like NTS and EATA and countably is inducted in police they are on eata base. All are graduated, master level and well qualified they comes with cream mind now the older concept is changing it will take time its still there but the majority is going to changing now the well educated people are working. exceptional cases are there but we discourage these type of things and we advise them we can justify your mistakes there is courses of ethics which dealing with public .

Q6: when you talk about the countering terrorism I start from Peshawar unfortunately geographically Peshawar location is multi and international interest are there. For a way tribes there interest is over her and they are working here . different type of militants groups worked here every group have own stratigy some one are sucide bomber someone are direct attacker etc against them the effective thing is we destroy from the top its not in open war they are living in our society they are mix in our colony to disturb this militant group we are operationing on a daily basis we register all the people and keep in view all the time . how many home are there which is the basement, Afghani accommodations all the data we have IBO they inform us and other intelligence and we work together . the basic thing is we have the coordinate with the intelligent agencies and we trace the target.

Q7:our first challenge is the shortage of strength the population of Peshawar is 1.4 million for that our strength is very less. The problem of Peshawar is police are not working on just line order but they also work in a security like to protect governor house, $\mathrm{cm}$ house, secetrate ,provincial assembly, high courts, judial complex etc. Mostly our strength is deployed were there . so in police station we are in shortage. Shortage of strength should be addressed . we have CVS system there is the app in mobile all of the FIRs are computerize. We have IVS and we have VVS system just like that we have a multiple gadget this need to be keep onward. And the next project called safe Peshawar all the city will be cover by cameras .this might be more effective. we have traced large amount of dacoits through a small number of cameras already.

Q8:OUR BASIC REFORM IS induction to eata even I is SP I don't have the authority to induct the simple ring root in the police department everyone is coming to the department on the basis of merit.and the second thing is the computerization of FIR which is linked to IVS, VVS, IBS .now the police is upgraded there is a school of investigation which keep the police upgrade to the modern era. Other schools of tactics and police school of IT. The police go there and return well trained and well equipped. The good thing is police is depoliticize and only IG is transferred the others.

Q9:the basic thing is about KP police we face the militance and combat from DIKHAN to DIR not even single district. We face the militence and we work in every single district. Police face on front line even in dara adam khail every where we work on front line that's why kp police is best police its never happen in Karachi and other cities

\section{$2^{\text {ND }}$ RESPONDENT}


Q1:As u know society is comprised of different people. There we can see people committing crime and our people need protection so kind of people there are so there is we have if they are not police there will be no law enforcement. Society is nothing if there is no law and rule. If there is no rule and law it will be no society. I think it will be just like a jungle where no humans are living so that's why law is very important and for law need agency and this agency is police. If the society within law the people who are powerful they will be dominant and these people will be run the society and weak person will be under the powerful or dominant peoples and there is the rights of every person and powerful peoples will not give his rights to weak peoples. Within limit maintaining there is rules and for these rules police is very important. That is implementation force so the rules are made and implemented by police force.so for society police is very important.

Q2:So my point of view society will be developing from begging the humans is contiounsly developing. Humans are passing through different stages and humans are developing if we study the history humans are developing. No body imagine that human will reach to the moon. As like human is developing it the same way police department is developed. And these police are also the part of society. That is the distribution of work that police is working in their own perspective and the others or their own. And police department is improved and improving day by day. If there is improving there will be achievements.as there is a new invention there is misuse also. The invention can create the opportunity some body use it for bad well and some body use it for good well so the police in counter they use the inventions in positive way. The invention gives the police achievements as the public is witness $u$ can ask.

Q3:Now a days there is no blind law inshaullah. Police is made for public service they are helping people according to their resources. Life and property basic thing if the humans and there property is not safe he cannot survive in the society therefore police is necessary and work for them and you can see the changes for some extend. Almost the duty of police is protection for life and for their property. And protect their rights and they are improving day by day from starting.

Q4:as for as the bribes question is concerned it the people thinks that police take bribes for the registration or cases or they do refusal due to political enforcement these are all the public concept but this is wrong there is no truth in it. Our police especially the Khyber Pakhtunkhwa police they are free of political pressure because our government do not want that the police will be politicked they want the police should be depoliticized and they do work under the rule of law. These are all the misconception of there is nothing there is no truth in it. We are taking all the bribes under our observation there is more the $99 \%$ which is lie. When somebody inters as a witness he speaks against the facts and try to dodge us and compels us for the bribes. And this is all in their own interest and they want us according to his interest. When they can't make it and failed then they complain about the bribes and these all are which is against the facts. This is our duty to watch the case from both sides and reach to the peaks. Police are helping more helping the poor people as compare to powerful. And we try to give more remedies to poor people. If the police don't give the remedies then where then they go. As for as my job concerned my son I join professional ASI. After different trainings I was promoted to Sub inspector and then inspector then DSP promotion and finally SSP promotion during this period without national police service I also join the

Page 23/31 
international police and United Nations police I Was a member of peacekeeping force of the United Nations in different countries. I went three time to abroad to servant in UN and this is the proud moment for our nation and especially for police department. As you think our people is always upset of police for many reason I don't know what it was our performance is always appreciated even a Un journal is print annually our country police our police stand is first are second position.so when the Un appreciated our work same police as here in custody. We are delivering our duties same as abroad.

Q5:as your question is concerned police never remain abusive they are always cooperative and helpful. Look I agree the local police of police station when sometime a person go to the police station may be due to their tight schedule of time look they are human being (lough) they are working 24 hours practically they are working. May be they are sometimes in stress they cannot of to the your satisfaction level.(lough) then you may be feel like they are abusive I think they are not they are always kind and cooperative because burden of the work you may give him time. maybe you think he give you less time that's why you judge him abusive you can see here all are busy you can imagine in the police station right here .we are totally not abusive we are cooperative and kind.

Q6:You know after the terrorism the police work has been increased for that purpose in KP and other provinces also. We have established in counter terrorism department CTD they deal with the terrorism and they are dealing very well. CTD is rename it was CAD .and reinforced reestablished and it was called CTD and reequipped in modern technology so it is a CTD and they are well trained in encountering the terrorism and they had work very well. And inshaullah now you can feel that the terrorism is almost control you can see it.

Q7:In under our country limited resources so for which we attain that might be enough. For the crime and countering we have different departments. Look In these departments we have intelligence, investigation, operations according to my opinion we don't have any fluctuation to encounter any terrorist. There is no reason like that. we can say according to our population ratio our police department is less in strength .look we are under developing country I can say we have enough Resources. We go on according to resources. We enough control the crimes and try to. I can say according to population we need resources as by improving our strength but in limited our result is good.

Q8Yes reforms are very effective we have now before we were having on the training schools initial training like that. Now we have specialized training schools they are giving training and investigation intelligence and right management you can say that they are specialized training courses which are very effective for the police which is improving the work of police now so reforms after reforms the police is delivering better $u$ can also feel that.

Q9:Yes I will comment on this but I can say that If you take the comment of public. Public they are appreciated us because our reforms is going better and better and we belong to the public and we work for the sake of them. We are the part of society and we want to improve ourselves just because the KP Police is better than others. The public cooperate very well and we trying to cooperate with as well. We 
win the trust of the public in trying. We have no tolerance for criminal and we are ready any time for public help.

\section{Conclusion}

After carefully examination and investigation of the key factors of peacekeeping in Peshawar from 20132018 it has been concluded that most of the good work have been done in last five years. The role of Police, that keeps and maintains peacekeeping and keep innocents from danger and un-avoidable circumstances. In this research, different types of investigations have been conducted that shows the good work in last five years as mentioned and discussed in Chapter 4. These are attempt to murder cases, suicidal, burglary cases, the kidnaping of kids with ransom cases etc. All these cases have been investigated from attendant's interviews. In this scenario, the attendants are the Police that keep peacekeeping in the society. The role of Police and the threats and dangers that they have faced from last five years have been concluded in this study. The recoveries of arms, ammunitions and drugs have also been investigated and the results are portrayed in tables and graphs for accurate understanding. In short, those aspects and factors that have a great impact on peacekeeping in Peshawar from 2013-2018 have been investigated and discussed from Police's superiors. Operations of Peacekeeping Missions were the dependent variable in this study. The study results lead to a conclusion that operations of peacekeeping missions is influenced by troop and police contributing countries, politics and bureaucracy and resources and logistical support.

\subsection{Recommendations}

The proposed study was conducted for the sake and investigation of peacekeeping in Peshawar from Year 2013-2018. This study also recommend that future directions of the peacekeeping in the existing desired area with much more accurate and ultimate investigations that will be year wise of monthly or should be from decade to decade that depends on the respondent's ideas and views. Human trafficking, forced prostitutions, illicit desires of the politicians and money laundering have also a great impact on peacekeeping. These issues also need to be solved properly with proper methods of investigations.

This study also suggests that further research be conducted on this field in various provinces experiencing conflict since there seems to be a correlation between these peacekeeping missions and sexual violence.

\section{Declarations}

Conflict of Interest: The Authors declare no conflict of interest or competing interest.

\section{References}

1) https://uk.sagepub.com/sites/default/files/upm-binaries/82671_Chapter_1.pdf 
2) https://www.definitions.net/definition/peacekeeping

3) Bergesen, A. J., \& Lizardo, O. (2004). International terrorism and the world-system. Sociological Theory, 22(1), 38-52.

4) Wills, D. C. (2004). The first war on terrorism: counter-terrorism policy during the Reagan administration. Rowman \& Littlefield Publishers.

5) Dr. Raza Khan August $31^{\text {st }}, 2015$ Published in The Express Tribune, The impact of Afghan refugees

6) Saeed, L., Syed, S. H., \& Martin, R. P. (2014). Historical patterns of terrorism in Pakistan. Defense \& Security Analysis, 30(3), 209-229.

7) https://en.wikipedia.org/wiki/2008_Peshawar_bombings (01:17 AM/22-June-2019)

8) Quraish, M. (2018). Peace-making Efforts in KP: An Analysis of MMA, ANP and PTI Governments (2002-18). Policy Perspectives, 15(3), 197-208.

9) Bellamy, A. J., Williams, P. D., \& Griffın, S. (2010). Understanding peacekeeping. Policy.

10) Schmidl, E. A. (1998). Police in peace operations (pp. 11-11). Landesverteidigungsakad, Militärwiss. Büro.

11) Sismanidis, R. D. (1997). Police functions in peace operations. Washington, DC: US Institute of Peace.

12) Greener, B. K. (2011). The rise of policing in peace operations. International peacekeeping, 18(2), 183195.

13) Krishnasamy, K. (2002). Pakistan's Peacekeeping Experiences. International Peacekeeping, 9(3), 103120.

14) Perito, R., \& Parvez, T. (2013). Empowering the Pakistan Police. United States Institute of Peace.

15) Abbas, H. (2011). Reforming Pakistan's police and law enforcement infrastructure. US Institute of Peace, Washington, DC.

16) Qurat-ul-Ain \& Qamar Cheema (2016) Pakistan's police and counter terrorism: challenges and policy options in the backdrop of internal security policy. National Defense University, Islamabad.

17) Bergeson, A. J., \& Lizardo, O. (2004). International terrorism and the world-system. Sociological Theory, 22(1), 38-52.

18) Wills, D. C. (2004). The first war on terrorism: counter-terrorism policy during the Reagan administration. Rowman \& Littlefield Publishers. 
19) Dr Raza Khan August $31^{\text {st }}, 2015$ Published in The Express Tribune, The impact of Afghan refugees

20) https://en.wikipedia.org/wiki/2008_Peshawar_bombings (01:17 AM/22-June-2019)

21) KPK Police Reforms Making a Model Police Force in the Country (JANUARY 10, 2017)

Figures

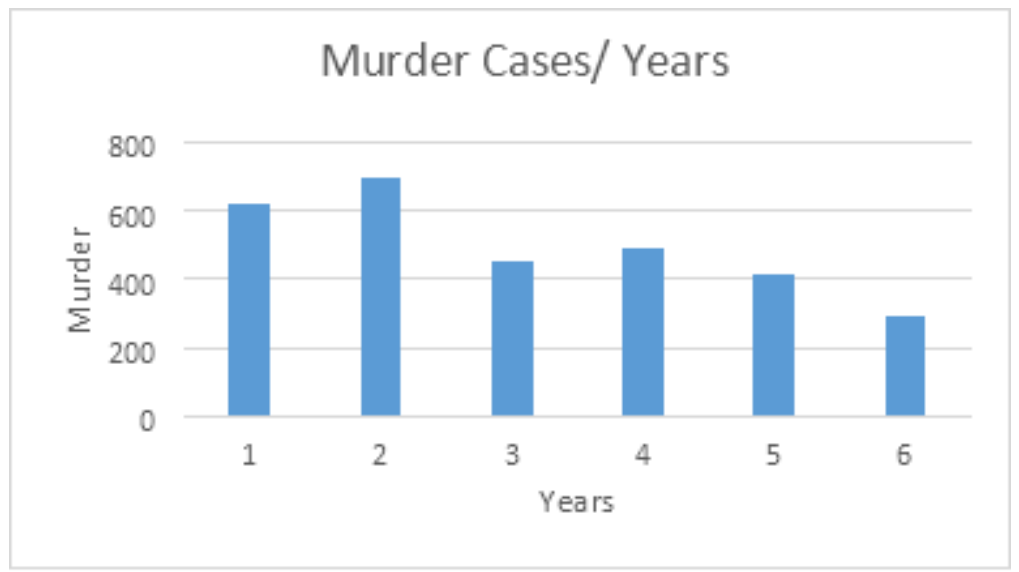

\section{Figure 1}

Murder Cases per year in Peshawar

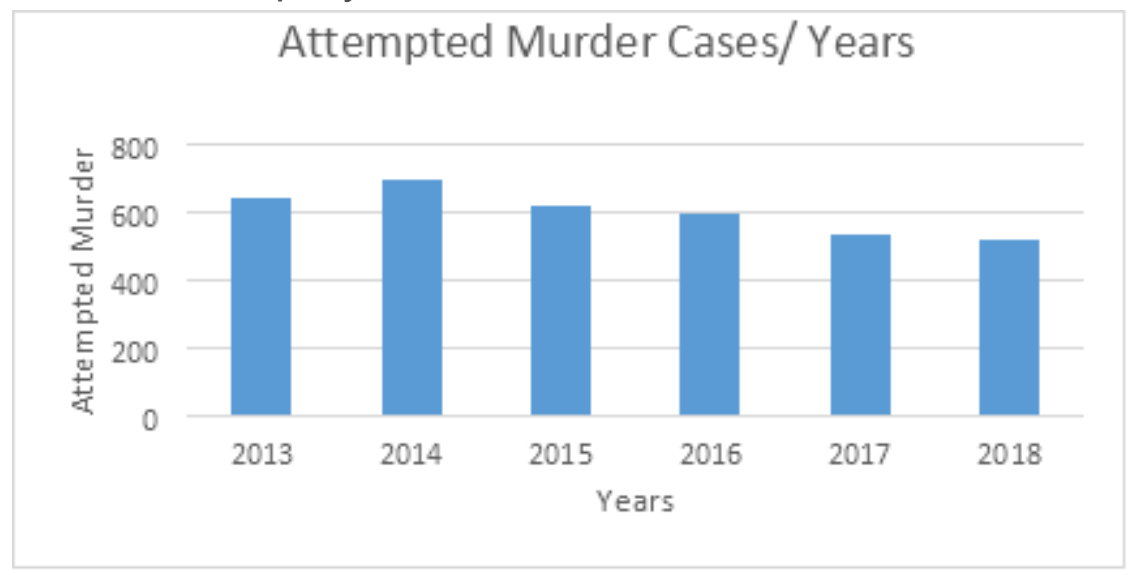

Figure 2

Attempted Murder Cases per year in Peshawar 


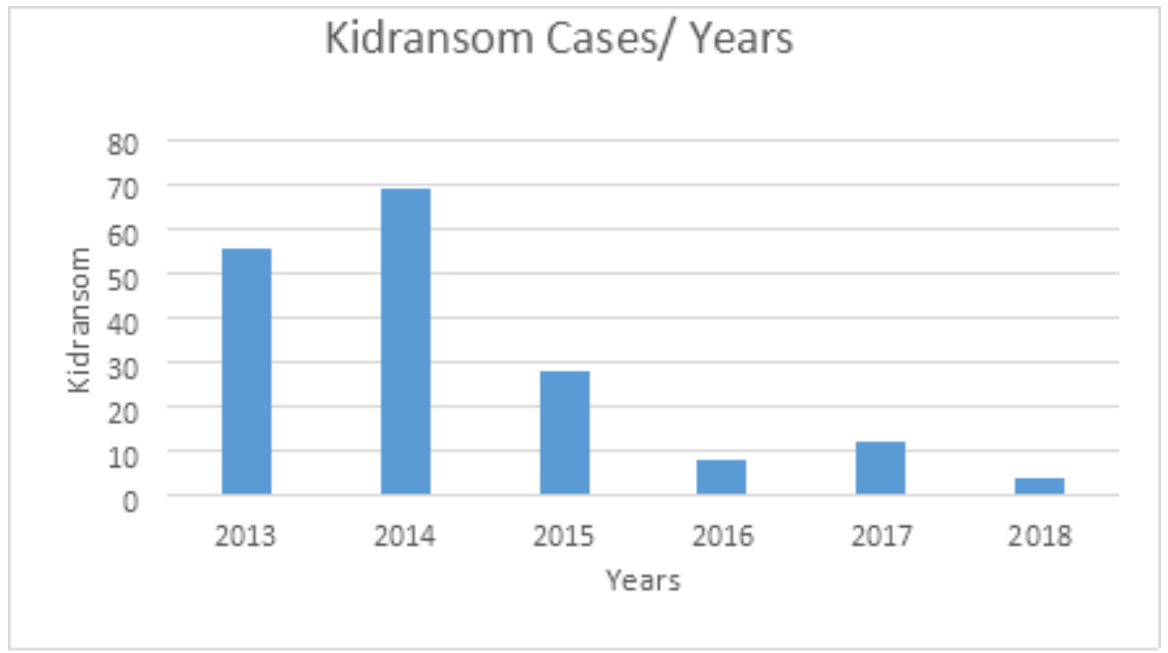

Figure 3

Kid Ransom cases per year in Peshawar

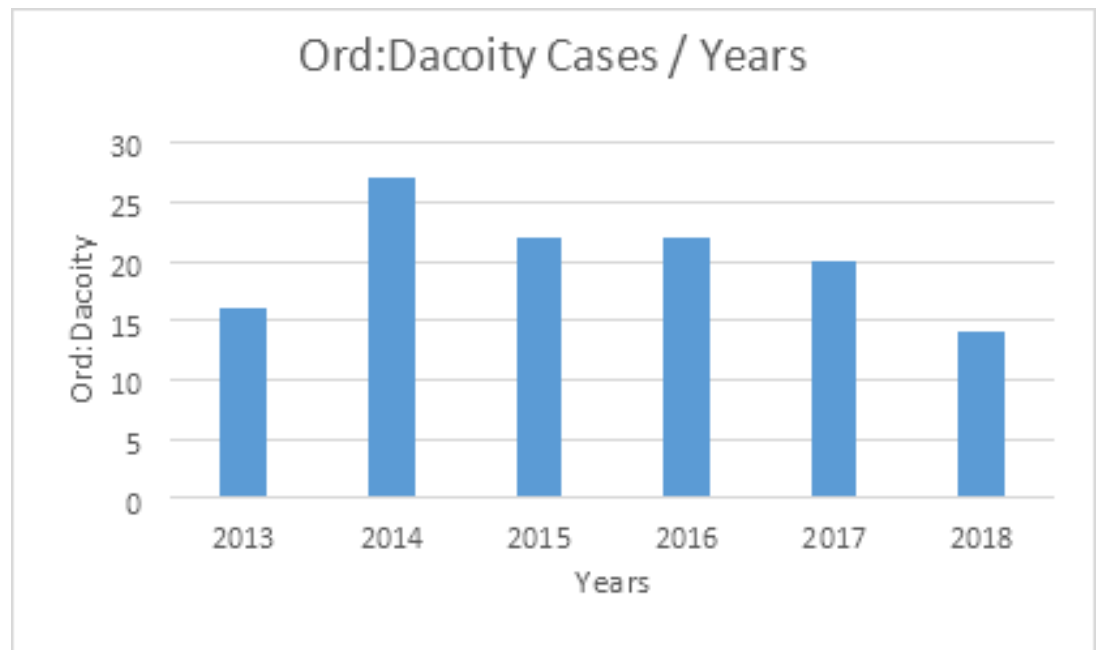

Figure 4

Ord:Dacoity Cases per year in Peshawar

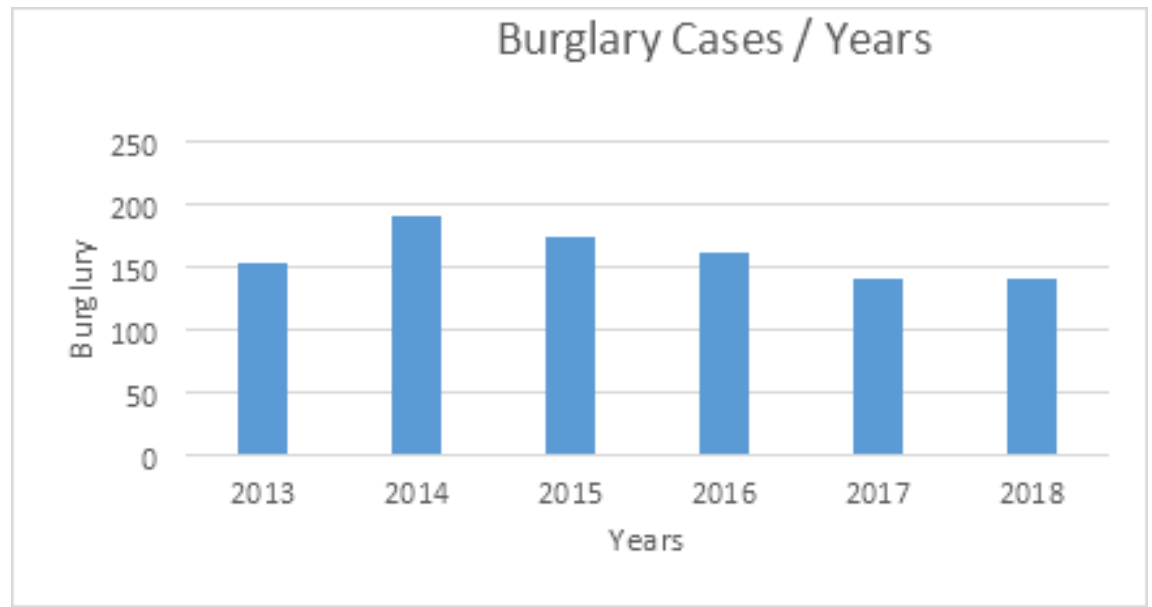

Figure 5 
Burglary Cases per year in Peshawar

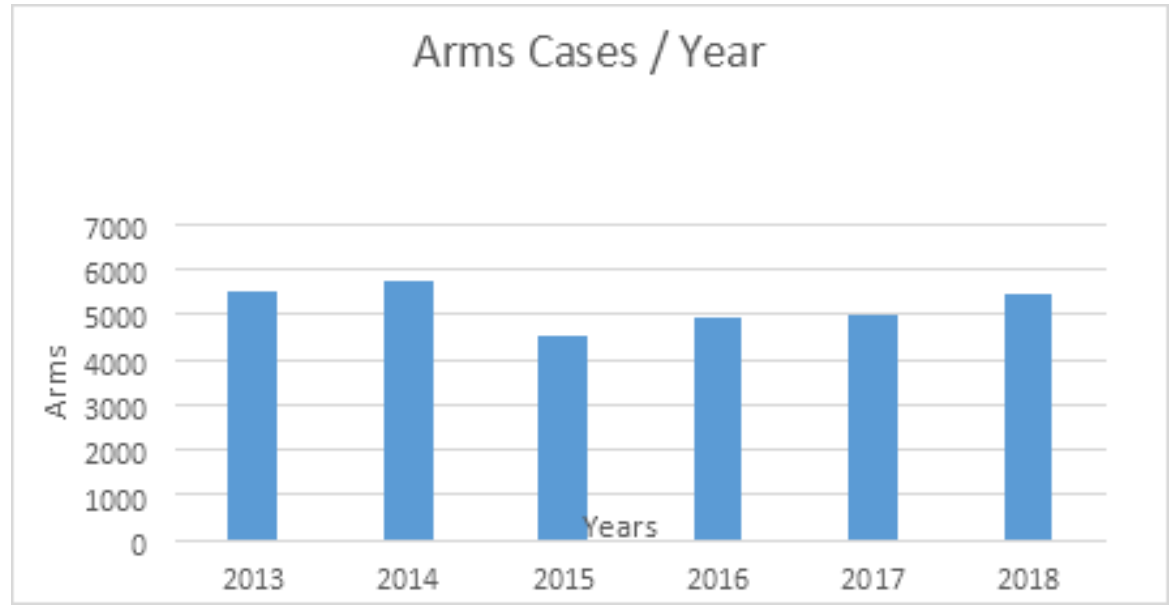

Figure 6

Arms Cases per year in Peshawar

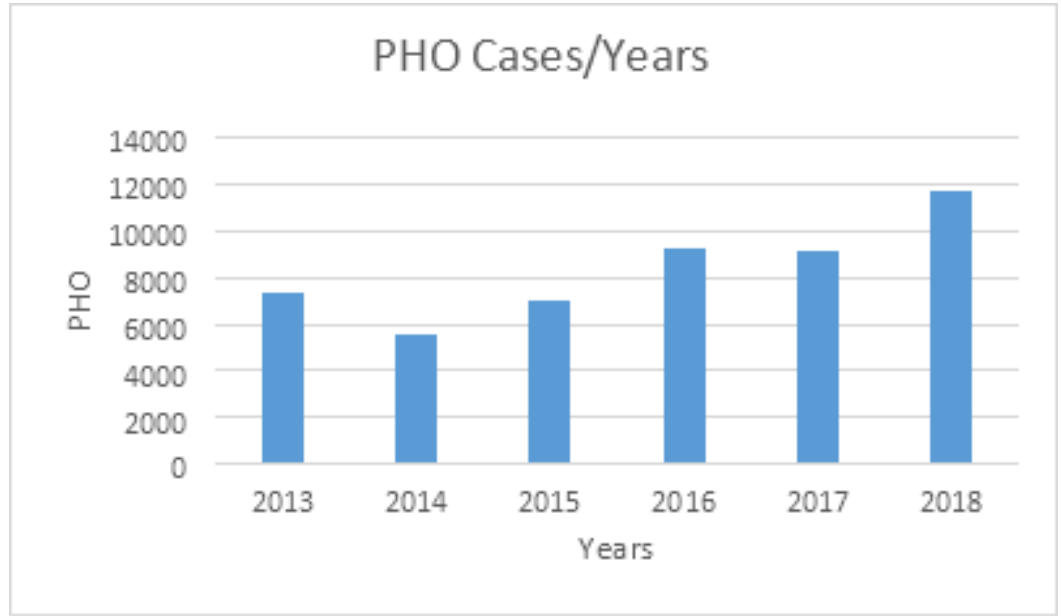

Figure 7

Potentially Hazardous Object Cases in Peshawar

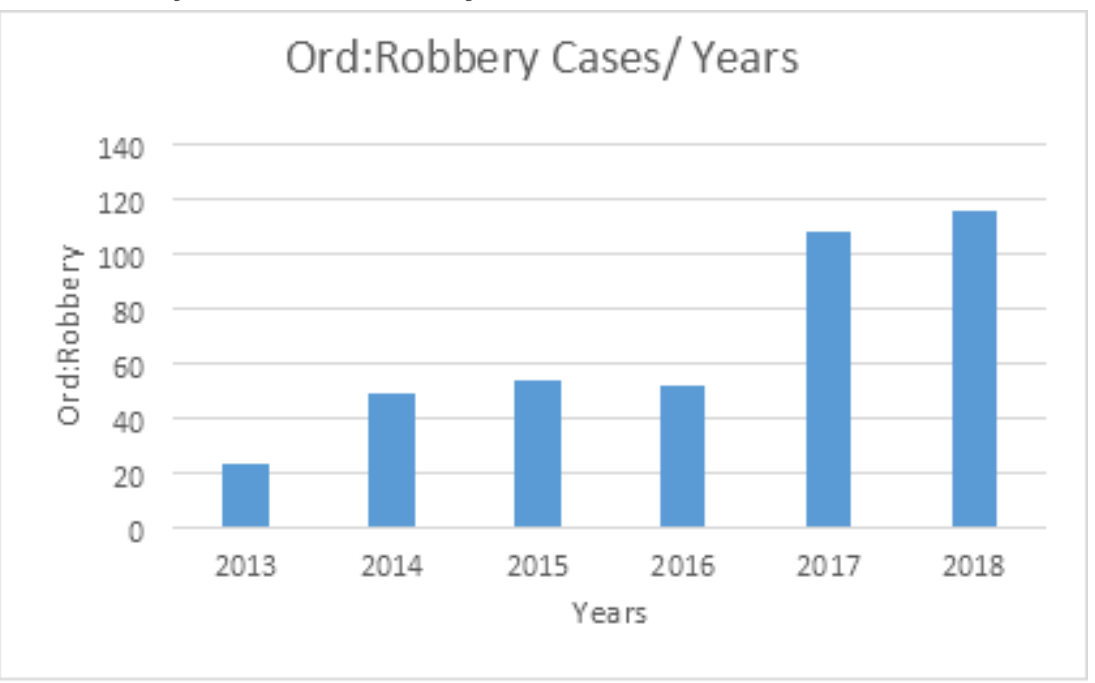


Figure 8

Ord: Robbery Cases per year in Peshawar

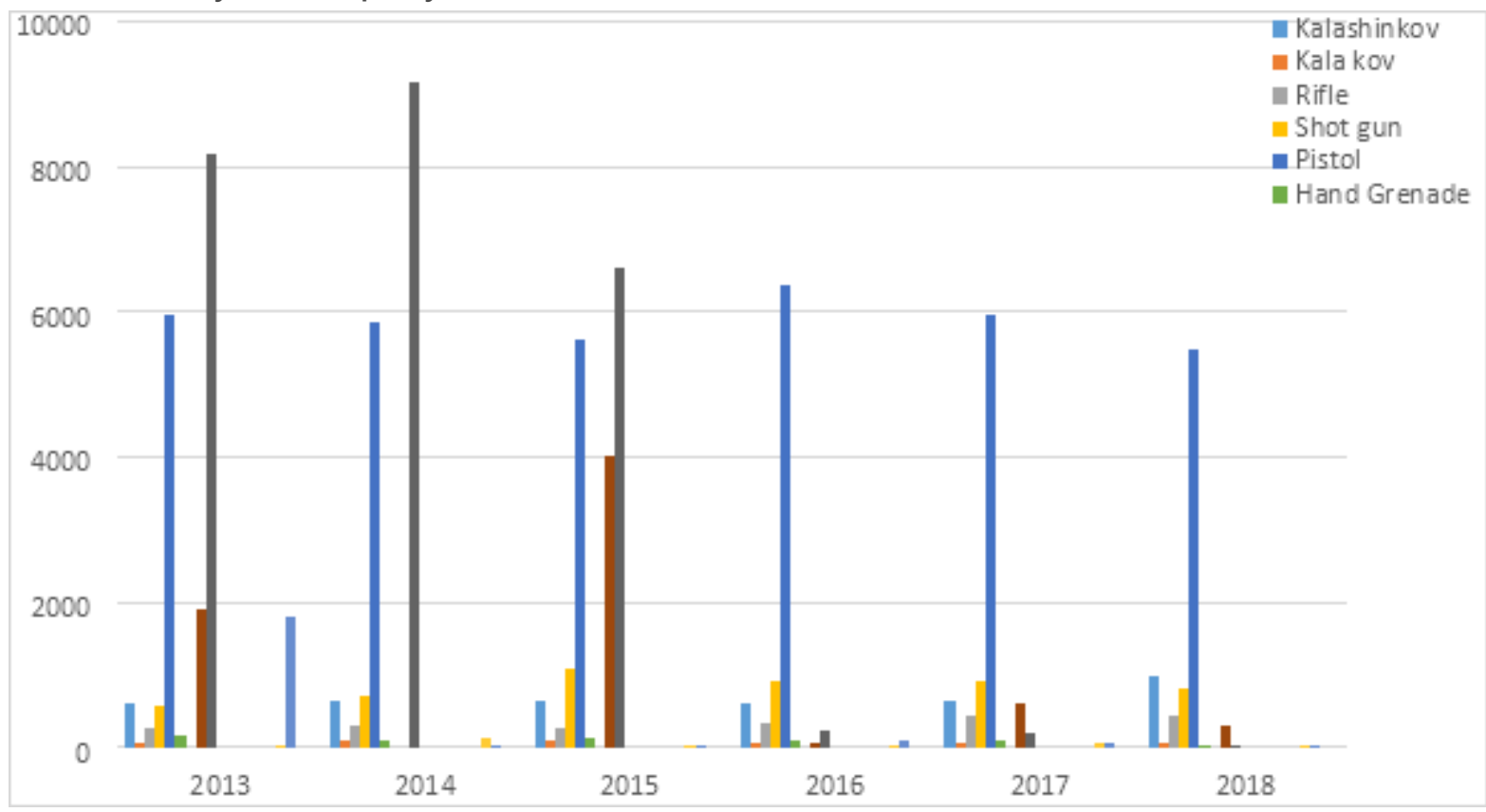

Figure 9

Figure 4.9 (a): Arms and Ammunitions; Recovery from 2013-2018

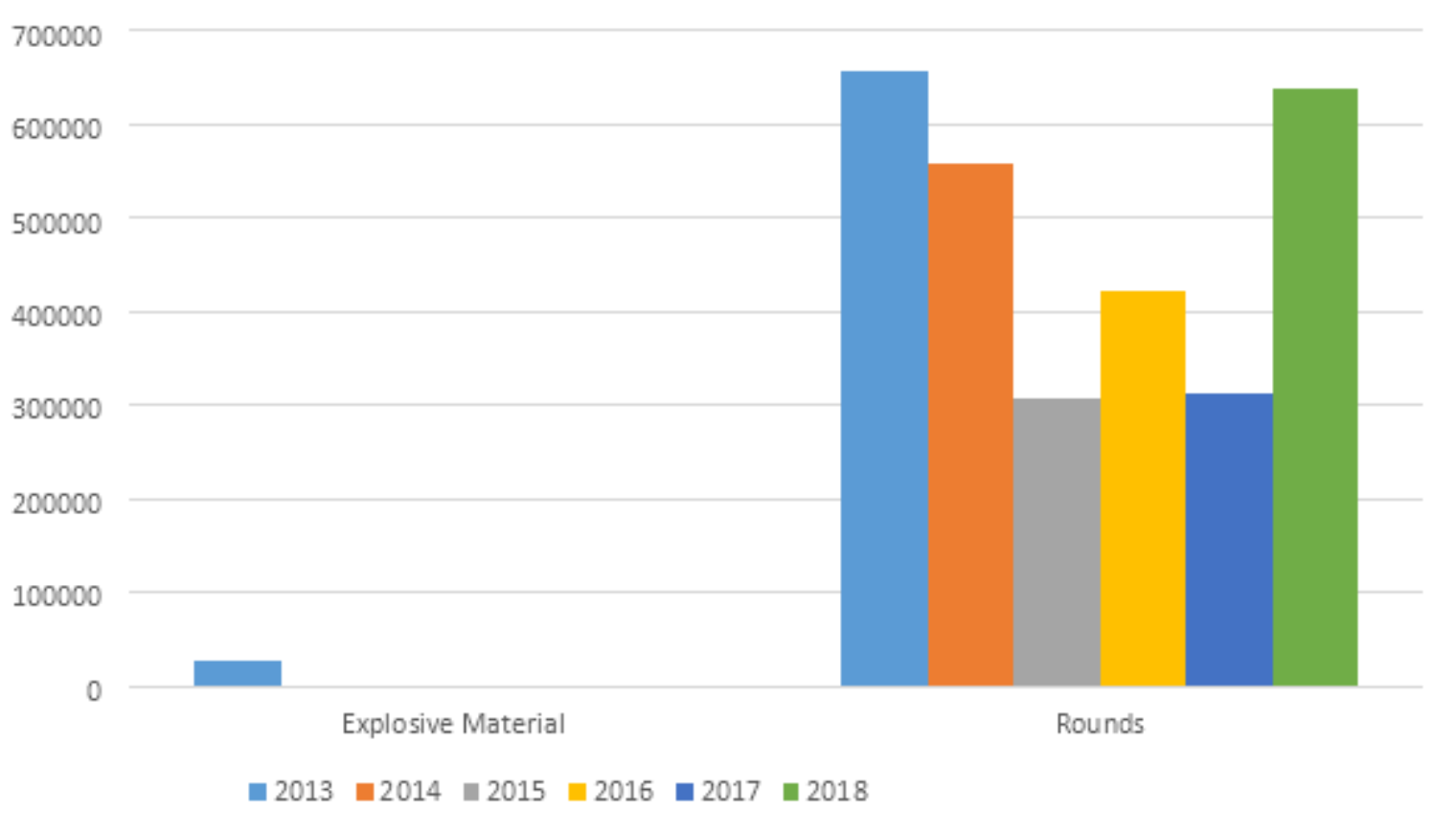

Figure 10

Figure 4.9 (b): Arms and Ammunitions; Recovery from 2013-2018 


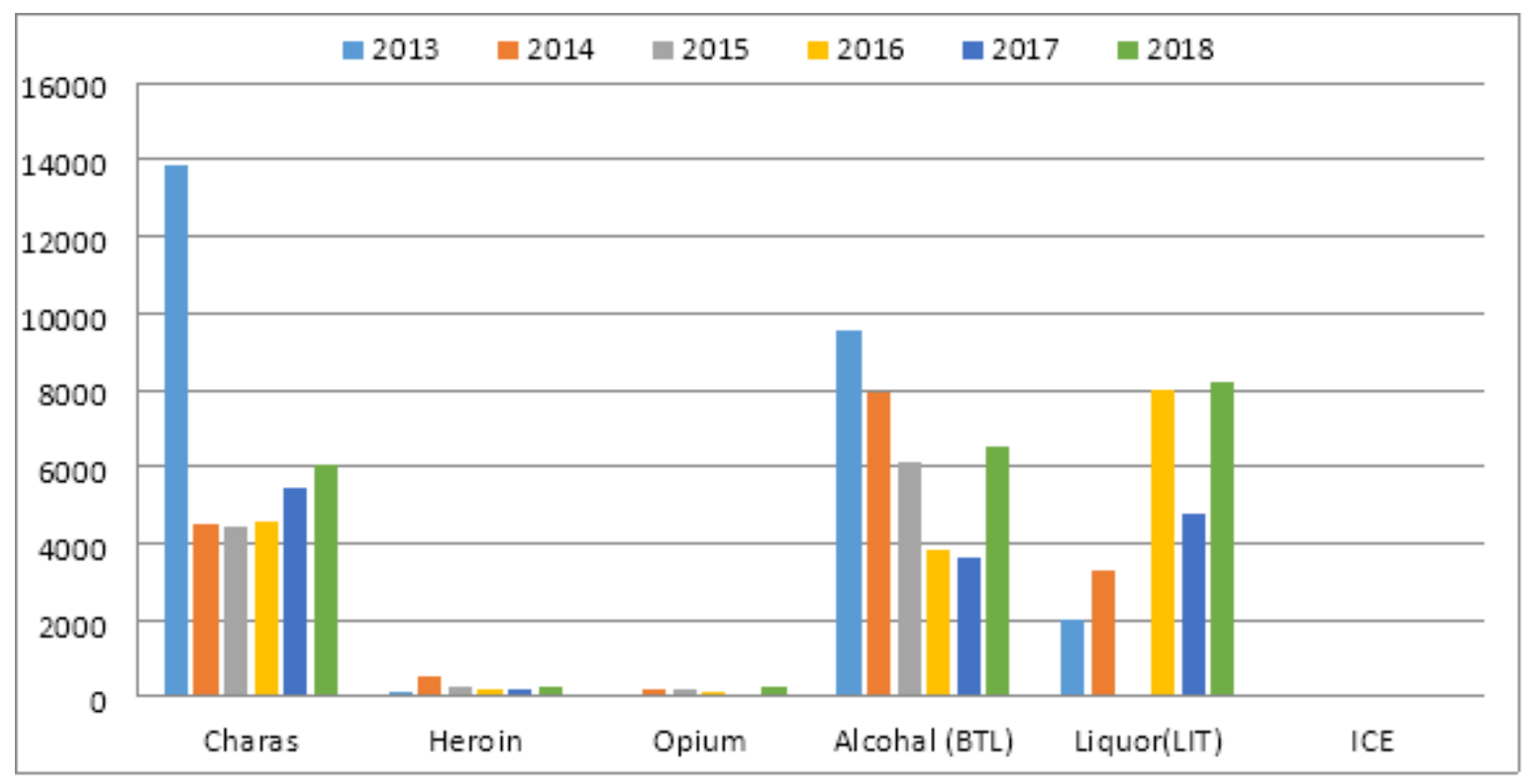

Figure 11

Figure 5.2: Recovery of Narcotics 